\title{
Supervision and Participation in Teachers Working Group Toward the Teachers' Professional Competence
}

\author{
Isniwati ${ }^{1}$, Erny Wahdini ${ }^{1}$, Muhammad Saleh ${ }^{2}$ \\ ${ }^{1}$ Master Program of Early Childhood Teacher Education, Universitas Lambung Mangkurat, Banjarmasin \\ 70123, Indonesia \\ ${ }^{2}$ Master Program of Education Management, Universitas Lambung Mangkurat, Banjarmasin 70123, \\ Indonesia
}

Article history:

Submission May 2020

Revised June 2020

Accepted June 2020

*Corresponding author:

E-mail: isniwati510@gmail.com

\begin{abstract}
Learning activities cannot be carried out with optimum results in case teachers have professional competence. Academic supervision by the school principals and professional learning community activities are two of the efforts which are conducted to improve teachers' professionalism competence in Indonesia, especially in kindergarten level. This study aims at finding out the effect of school principal supervision and participation of the kindergarten teachers in Teacher Working Group (TWG), a kind of professional learning community, towards the kindergarten teachers' professional competence. There were 57 kindergarten teachers involved in this study. Data of the study were collected through questionnaire. The collected data from the result of the questionnaire were analyzed using multiple regression statistical analysis. Statistically, the results of the study show that academic supervision of quality achievement conducted by the school principals and teachers' participation in TWG have a significant effect on teachers' professional competence. For this reason, the following suggestions are made: (1) It is necessary for teachers to develop a positive mindset about the benefits of academic supervision; (2) teachers also need to actively participate in TWG activities; and (3) school principals needs to be closer to teachers.
\end{abstract}

Keywords: Professional competence, academic supervision, TWG parricipation

\section{Introduction}

Teachers play an important role in improving the quality of education, especially at the Early Childhood Education level in kindergartens, where basic knowledge and skills are provided. The quality of a teacher will influence the achievement of the students. Good teachers, who give sufficient attention to their students, can help the students to improve their academic achievement (Kiany \& Shayestefar, 2011). In addition, teachers' non-verbal communication during teaching and learning process will shape students' mood to study and at the same time will affect students' achievement (Bambaeeroo \& Shokrpour, 2017).

Though, being a professional teacher is not an easy thing because there are many things that need to be done and mastered by the teachers. In doing their job, teachers should have self-efficacy and enthusiasm in teaching the students, because those elements will influ- ence students' participation during the teaching and learning process (Mahler, Großschedl, \& Harms, Does motivation matter? The relationship between teachers' self-efficacy and enthusiasm and students' performance., 2018). In order to deliver a quality instruction a teacher should also be able to detect their students' competencies (Dybowski et al., 2017). In addition, teachers should be able to identify students' learning strategies since they may influence students' achievement (Muelasa \& Navarroa, 2015). Furthermore, teachers also need to adjust the teaching strategies to suit students' learning styles in order to create effective teaching and learning process to improve students' achievement (Tulbure, 2012). In this digital era, it is also a must for teacher to master information and communication technology and use them in the teaching and learning process (Dalle \& Ariffin, 2018). It is because the use of current technology during teaching

How to cite:

Isniwati, Wahdini, E., \& Saleh, M. (2019). Supervision and participation in teachers working group toward the teachers professional competence. Journal of K6, Education, and Management, 2 (4), 292 - 300. doi: 10.11594/jk6em.02.04.04 
and learning process may help the students to learn effectively (Baharuddin \& Dalle, 2017).

From those explanation above, it can be understood that teachers have a great role in students' achievement. However, the expected professional competence may not be fully achieved by the teachers because professional competence is a long and continued process. As the case in the Kapuas Kuala sub-district area, the data from the Kapuas Kuala District Education Office in 2019 show some critical information. The number of private teachers in kindergarten level is 66 teachers, consisting of those with undergraduate level education of 23 $(34.8 \%)$ and $43(65,2 \%)$ were graduated from Senior High School Level. Only $22.6 \%$ of teachers met the academic qualification standards. This percentage is not in line with the current demands in which every professional teacher is required to have a minimum education of Bachelor degree. The data presented show that the readiness of kindergarten teachers in Kapuas Kuala sub-district in terms of professional competence is still a major problem that needs immediate improvement.

Based on the data above, kindergarten teachers in Kapuas Kuala sub-district area have to improve their professional competence, since only professional teachers could help the students to reach their optimum potential. In order to improve their professional competence, joining a professional learning community can be an alternative. Professional learning community will help the teachers to improve their quality through collaborative learning, where the teachers can have a discussion with other teachers based on their specific needs and problems (Jong et al., 2019).

The participation of teachers in a professional learning community is also reported to be successful in improving teachers' teaching skills (Luyten \& Bazo, 2019). Not only the face to face activity of professional learning community is confirmed to give positive impact on teachers' performance, but the online professional learning community activities also could give significant effect on teachers' performance (Zhang \& Liu, 2019). Teachers Working Group
(TWG) is a kind of professional learning community which aims at increasing the ability of teachers in kindergarten. It is a forum of professional activities for kindergarten teachers at the sub-district level (National Education Department, 2009). It is a professional coaching forum incorporated in school group organizations. The program is held once per month to improve the quality of education. In addition, improving teachers' professional competence is also can be done through academic supervision (Idris, 2016). Academic supervision is the assistafnce given to teachers to continuously develop their competencies and improve the achievement of learning objectives (National Ministry of Education, 2009). The one who is in charge of doing academic supervision in Indonesian Education system is one of the school principle responsibilities, but it is also can be done by involving other professionals or educational practitioners. If it is conducted properly, supervision practice will have significant effects on teachers' work performance (Yousaf et al., 2018).

Considering the important role of teachers in students' achievement, the function of professional learning community, and supervision in improving teachers' professional competence this study tried to find out the effect of teachers' participation in TWG and the school principal academic supervision towards teachers' professional competence. It is expected that this study could give a clear picture about whether or not TWG and academic supervision conducted by the school principal effective to improve teachers' professional competence. This study also can be an initial study to identify things that may improve kindergarten teachers' professional competence in Kapuas Kuala sub-district for other researchers.

\section{Material and Methods}

This research uses a causal explanatory model, which is used to examine the influence of one or more independent variables on dependent ones. Explanatory research aims to teachers' professional competence can be seen in Table 1. 
Table 1. Descriptive Statistics of Teacher Professional Competence

\begin{tabular}{lcccc}
\hline & Mean & SD & Minimum & Maximum \\
\hline $\begin{array}{l}\text { Teachers' Profes- } \\
\text { sional Compe- } \\
\text { tence }\end{array}$ & 71.0351 & 6.05323 & 55.00 & 80.00 \\
\hline
\end{tabular}

The average of each teacher professional competence indicator is shown in Table 2 . Based on the results in Table 2, the average explain the relationship between two or more symptoms or variables. Since the study aims to explain the cause of an event, various variables outside the problem need to be identified to ascertain the cause of a problem.

Explanatory research shows the correlation between two or more variables, including the patterns, directions, properties, shapes, and strength of the relationship. It often begins with an explicit question, "Is there a relationship between $\mathrm{X}$ and Y?" The answers to these questions can be obtained only through an explanatory study. Causal explanations examine the causes of some events or phenomena. These are very common types of explanation used in case there is a cause and effect relationship.

The sample of the study consists of 57 kindergarten teachers in Kapuas Kuala subdistrict area. Those teachers were given questionnaire in order to collect the data about teachers' professional competence, supervision quality and TWG participation. The collected data were analyzed using multiple regression statistical analysis in order to find the effect of supervision and TWG participation toward teachers' professional competence.

\section{Results and Discussion}

Based on the result of descriptive statistical analysis, it was found that the lowest and highest professional competence values are 55 and 80 , respectively. The standard deviation was 6.053 with an average value of 71,035 . The result of descriptive statistics analysis of the teachers' professional competence can be seen in Table 1.

The average of each teacher professional competence indicator is shown in Table 2 . Based on the results in Table 2, the average Professional Teacher Competency was 3.38.
The highest average indicator of Teachers Professional Competence is Developing Learning theme materials that are creatively taught with a value of 3.68. The lowest is utilizing information and communication technology to develop with a value of 3.04. This shows that the professional competence of kindergarten teachers is quite good. The teacher continues to develop learning materials by utilizing available information technology.

Hypothesis testing shows the effect of supervision of the quality academic achievement and teacher participation in TWG on the professional competence of teachers had a $95 \%$ confidence level. The testing was based on the SPSS 25.0 statistical computer program. T-test results are presented in Table 3. Mathematically multiple linear regression equations can be developed as follows:

$$
\begin{aligned}
& Y=\alpha+\beta_{1} X_{1}+\beta_{2} X_{2} \\
& Y=35.770+0,216 X_{1}+0,223 X_{2}
\end{aligned}
$$

Based on the multiple regression equation, the explanation can be given as follow:

1. The constant value $(\alpha)$ is 35,770 . In case the variables X1 and X2 are zero, then the teacher's professional competence is 35,770 . This means that before teachers are supervised for quality academic achievement in their competencies, they try to improve their professional competence.

2. The value of the regression coefficient $\beta 1 \mathrm{X} 1=0.216$ indicates that the supervision of quality academic achievement (X1) has a positive influence on teacher professional competence. This means that an increase of the supervision variable (X1) by 1 increases the professional competence of teachers by 0.216 .

3. The regression coefficient $\beta 2 \mathrm{X} 2=0.223$ indicates that teacher participation in TWG (X2) has a positive effect on professional 
competence. This means that if each teacher participation variable in TWG (X2) increases in one unit, their professional competence also increases by 0.223 .

4. The Adjusted R Square value of 0.508 is equivalent to $50.8 \%$, which means that the influence magnitude of the two variables including supervision of quality academic achievement and teacher participation in TWG toward teacher professional compe- tence is $50.8 \%$. The remaining $49.2 \%$ is influenced by other variables not examined in this research.

5. The $\mathrm{F}$ test results show that there is a significance value of $0,000<\alpha$ and $F_{\text {count }}=$ 29,910 and $F_{\text {table }}=3,168\left(F_{\text {count }}>F_{\text {table }}\right)$. This means that supervision of academic achievement and the quality of teacher participation in the TWG affects professional competence.

Table 2. Mean Score of Teachers' Professional Competence for Each Indicator

\begin{tabular}{lc}
\hline \multicolumn{1}{c}{ TEACHER PROFESSIONAL COMPETENCY INDICATOR } & MEAN \\
\hline $\begin{array}{l}\text { Mastering Material, Structure, Curriculum, Basic Concepts, Early Childhood } \\
\text { Guidelines }\end{array}$ & 3.39 \\
$\begin{array}{l}\text { Mastering the Formulation of Standards Operational Procedures for early } \\
\text { childhood education unit }\end{array}$ & 3.53 \\
$\begin{array}{l}\text { Developing a learning theme material that is taught creatively } \\
\text { Developing professionalism sustainably by taking reflective action }\end{array}$ & 3.68 \\
$\begin{array}{l}\text { Utilizing information and communication technology to develop themselves } \\
\text { THE MEAN OF PROFESSIONAL TEACHER COMPETENCY }\end{array}$ & 3.11 \\
\hline
\end{tabular}

Table 3. The influence of supervision on the quality of academic achievement and teacher participation in TWG on teacher professional competence

\begin{tabular}{lcccc}
\hline \multicolumn{1}{c}{ VARIABLE } & $\begin{array}{c}\text { REGRESSION } \\
\text { COEFFICIENT } \\
\text { (B) }\end{array}$ & T-COUNT & SIGNIFICANCE & CONCLUSION \\
\hline $\begin{array}{l}\text { Academic Supervi- } \\
\text { Sion }\end{array}$ & 0.216 & 4.069 & 0.000 & Ha1 is accepted \\
Participation in TWG & 0.223 & 4.952 & 0.000 & Ha2 is accepted \\
\hline$F_{\text {count }}$ & $: 29.910$ & $: 0,000$ & $t_{\text {table }}= \pm 2.005\left(\mathrm{df}_{(\mathrm{n}-2-1 ; \alpha=5 \%)}=57-2-1\right)$ & \\
Sig.F & $: 35.770$ & Adjusted $R$ Square: $0,508 \approx 50,8 \%$ & \\
constant $(\alpha)$ & SE: 4.663 & \\
$\mathrm{f}_{\text {table }}= \pm 3.168\left(\mathrm{df}_{1}=2, \mathrm{df}_{2}=54\right)$ & &
\end{tabular}

The hypothesis test with the t-test presented in Table 3. shows the following:

1. Hypothesis testing I

The t-test results showed that the t-count of supervisors for quality academic achievement (X1) was 4,069 while the $t_{\text {table }}= \pm 2.005$ ( $t_{\text {-count }}>$ $\mathrm{t}$-table). This is also indicated by the significance value $(p)=0,000$ while the value $\alpha=0.05$ as a predetermined level $(p<\alpha)$. Therefore, Ha1 is accepted, and Ho1 is rejected, which means supervision of quality academic achievement has a significant effect on teacher professional competence. Based on the test results, the regression coefficient for the supervision of quality academic achievement (X1) is 0.216 , as indicated by the standardized coefficient beta.

2. Hypothesis Testing II

The t-test results show that the $t_{\text {count }}$ of teacher participation in TWG (X2) is 4,952 
while the value of $t_{\text {table }}= \pm 2,005$ ( $\left.t_{\text {count }}>t_{\text {table }}\right)$. This is also indicated by the significance value (p) $=0,000$ while the value $\alpha=0.05$ as a predetermined level $(p<\alpha)$. Therefore, Ha2 is accepted, and Ho2 is rejected. This means teacher participation in TWG has a significant effect on teacher professional competence. Based on the test results, the regression coefficient for teacher participation in TWG (X2) is 0.223 , which is indicated by the standardized coefficient beta.

The result of the study shows that supervision of academic achievement quality has a significant influence on the professional competence of kindergarten teachers.

The results showed that Ha1 was accepted, which means the supervision of academic quality achievement had a significant influence on the professional competence of kindergarten teachers $\left(t_{\text {count }}>t_{\text {table }}\right.$ and $\left.p_{\text {value }}<0.05\right)$. The result of this research is in line with Mardiyono (2001), which established that in case academic supervision activities are often carried out professionally by supervisors, it improves the quality of teaching. This result is also supported by the study conducted by Puspowati (2003), which concluded that there was a significant relationship between supervision of class visits and teacher performance in the District of West Semarang. Supervision of class visits encourages teachers to improve work performance, achievement, and results. Furthermore, the study that was conducted by Iroegbu \& Etudor-Eyo (2016) also found that principal instructional supervision also increases the teachers' effectiveness in doing the teaching and learning process. Supervision practice conducted by school principals in Pakistan primary schools is also reported to have significant effects on teachers' work performance (Yousaf et al., 2018).

Similar finding also found by Ampofo et al., (2019), in which lesson planning supervision and lesson delivery supervision can improve teachers' performance. Another study that confirms supervision has a great impact on teachers professionalism is the study that was conducted by Idris (2016) who identified that strict supervision can improve teachers' professional competence.
This indicates that each school supervisors acknowledge the need for academic supervision. They plan it very well by referring to the foundations of supervision, conveying objectives, determining the form of approach, presenting the area to be supervised, compiling an implementation schedule, making operational designs, identifying resources, and conveying the target.

In its implementation, academic supervision is carried out in an ongoing basis and prioritizes placing teacher competency growth, open in implementing supervision, solving the problems faced by teachers, involving teachers, apply the approach appropriately, use techniques fittingly, utilizing various sources, and applying information technology.

In addition, the way that the supervisor conduct the supervision is proven to have a significant contribution towards teachers' professionalism (Aldaihani, 2017). Since supervision takes an important role towards the teachers' professionalism, the quality of supervisors should be assured so that the supervision runs as it is expected (Ozdemir \& Yirci, 2015). In order to do that, special trainings should be conducted for the supervisors to improve their quality (Sarfo \& Cudjoe, 2016). Since in normal school system, school principal is the one who conducted the supervision to the teachers, then it is suggested that all principal should be trained so that they can be a good supervisor and evaluator in order to improve the teachers' professionalism (Kraft \& Gilmour, 2016).

The results showed that $\mathrm{Ha} 2$ was also accepted. This means that teacher participation in TWG has a significant influence on kindergarten teacher professional competence (tcount $>$ ttable and pvalue $<0.05$ ). The results of this research are in line with Broto Sedjati (2001), which established that there is a positive and significant relationship between teacher participation in TWG and their professional abilities.

The result of this study is supported by the study conducted by Khan \& Abdullah (2019) who found that training can improve the teachers' productivity in Iraq. Similar finding is also found by Hervie \& Winful (2018), the result of their study shows that in-service training improves the teachers' performance in Ghana. 
The study that was conducted by Eze (2016) also confirms that re-trainings for the in-service teachers are able to improve their performance. However, it should be taken into account that various trainings will impact differently, therefore a good selection of training that can motivate teachers to learn should be done (Kennedy M. M., How does professional development improve teaching?, 2016). There are three types of trainings which are reported to be effective in improving teachers' teaching quality, namely training that focusing on teaching behaviors, increasing content knowledge, and strategic thinking (Kennedy, 2019). Furthermore, the knowledge that the teachers gain from a professional learning experience and learning practice can be a beneficial knowledge to improve students' learning success (Timperley \& Alton-Lee, 2008). Another thing that is important in teacher training is that there should be a system that motivates the teacher to implement the knowledge that they got from the training in the teaching and learning process (Osman \& Warner, 2020). Moreover, the duration of the training influences the success of the training to improve teachers' performance, it means that a training should be conducted in a sufficient duration (Hubers et al., 2020). Furthermore, in order to get the complete benefits of a training, complete participation is required (Jhang, 2019).

In terms of training model, the study that was conducted by Koellner \& Jacobs (2015) found that Problem Solving Cycle model is effective in helping the teachers to increase their performance and improve their students' achievement. Another training model that is also reported to be successful is a cross-sectoral approach, where teachers from different sectoral can discuss a particular teaching problem from various settings (Hamilton, 2020). Professional development though lesson study that involves collaborative activities of beginning and experienced teachers also can be an effective way to improve teachers' professionalism (Coenders \& Verhoef, 2019). However, in order to create a continuing professional development, Kennedy (2005) suggests that the training should move from transmission, through transitional to transformative catego- ries. In order to do that a continued professional development should be conducted. Continued professional development program that is led by practitioner can make teachers more productive (McChesney \& Aldridge, 2019).

From the policy maker pint of view, things which are needed to be considered before deciding to conduct a training for the teachers are the teachers' motivation and the aspirations of the teachers before joining the training (Avidov-Ungar, 2016). Moreover, since motivation and teachers' aspirations are very important in the success of a professional development program, reading research and joining in a free-time education based on teachers' need are also found effective in improving teachers' professionalism (Maaranen et al., 2020).

TWG is a professional coaching forum for teachers belonging to play group (Early Childhood Education) groups that aims at improving the quality of education. The play group is a combination of 3-8 kindergartens which have a common goal and spirit of progress in improving the quality of education through a professional coaching system. The coaching is given to teachers emphasizes professional service assistance based on their needs of teachers. The aim is to enhance the professional abilities of kindergarten teachers in improving the quality of the process and learning outcomes by utilizing all the resources and potential owned by the school, education staff and the surrounding community.

Even though TWG is important to improve teachers' professionalism, but it is also should be considered to avoid any activities that can crate teachers' tension that will bring negative effect on their performance (Schaap, et al., 2019). Based on the result of the study conducted by Schaap \& Bruijn (2018) there are seven things needed to be considered in the development of professional learning community effective, namely task perceptions, group composition, tensions between roles, beliefs about alignment, reflective dialogues, socialization and ownership. Furthermore, in order to maximize the effectiveness of the professional learning community, support from school principal is really needed Balyera et al. (2015). 


\section{Conclusion and Recommendation}

Based on the results and discussion, the following conclusions are made. They are: (1) the academic supervision quality influences the professional competence of kindergarten teachers. The better the quality of the academic supervision, the better professional competence of the teachers will be (2) the participation of teachers in TWG activities influences the teachers' professional competence. It means, better teacher participation in the TWG leads to a higher professional competence of kindergarten teachers; and (3) Better of academic supervision and the quality of teacher participation in the TWG is followed by the increasingly high professional competence of kindergarten teachers.

The following suggestions are also made. First, it is necessary for teachers to develop a positive mindset about the benefits of supervision of academic achievement quality. They also need to actively participate in TWG activities as a way to develop their professional competence. Second, supervisors need to be closer to the teacher and show that the academic supervision carried out is not merely an assessment, but rather a joint discussion effort in order to improve the quality of learning. This help teachers to develop the right perception of academic supervision. Third, this research only examined the effect of academic supervision and teacher participation in TWG toward the professional competence of kindergarten teachers in Kapuas Kuala sub-district, Kapuas Regency. Therefore, it is still necessary to do further research for teachers and principals to be more professional in carrying out their duties.

\section{Acknowledgment}

The authors express their gratitude to the head of the secretariat program and lecturers from the Graduated Program for Early Childhood Teacher Education at Lambung Mangkurat University in Banjarmasin for the input and suggestions in writing this research. They are also grateful to the head of UPT (Technical Implementation Unit) Education Office Kapuas Kuala sub-district Supervisor, Principals and Teachers in the sub-district of Kapuas Kuala for their support.

\section{References}

Aldaihani, S. G. (2017). Effect of prevalent supervisory styles on teaching performance inkuwaiti high schools. Asian Social Science, 13(4), 25-36. doi:https://doi.org/10.5539/ass.v13n4p25

Ampofo, S. Y., Onyango, G. A., \& Ogola, M. (2019). Influence of school heads' direct supervision on teacher role performance in public. IAFOR Journal of Education, 7(2), 9-26.

Avidov-Ungar, O. (2016). A model of professional development: Teachers' perceptionsof their professional development. Teachers and Teaching: Theory and Practice, 22(6), 653-669. doi:http://dx.doi.org/10.1080/13540602.2016.1158955

Baharuddin, \& Dalle, J. (2017). Interactive Courseware for Supporting Learners Competency in Practical Skills. TOJET: The Turkish Online Journal of Educational Technology, 16(3), $1-13$

Balyera, A., Karatasa, H., \& Alcia, B. (2015). School principals' roles in establishing collaborative professional learning communities at schools. Procedia - Social and Behavioral Sciences, 197, 1340-1347. doi:10.1016/j.sbspro.2015.07.387

Bambaeeroo, F., \& Shokrpour, N. (2017). The impact of the teachers' non-verbal communication on success in teaching. Journal of Advances in Medical Education \& Professionalism, 5(2), 51-59.

Coenders, F., \& Verhoef, N. (2019). Lesson Study: Professional development (PD) for beginning and experienced teachers. Professional Development in Education, 45(2), 217-230.

Dalle, J., \& Ariffin, A. M. (2018). The Impact of Technologies in Teaching Interaction Design. Journal of Advaced Research in Dynamical and Control System, 04(special issue), 1779-1783.

Dybowski, C., Sehner, S., \& Harendza, S. (2017). Influence of motivation, self-efficacy and situational factors on the teaching quality of clinical educators. BMCMedical Education, 17(1), 84-95. doi:https://doi.org/10.1186/s12909-017-09232

Eze, T. A. (2016). Teachers' perception of the impact of training and retraining on teachers' productivity in Enugu State, Nigeria. Journal of Research in Business and Management, 4(3), 33-37.

Hamilton, M. (2020). Evidence-based portfolios: a cross-sectoral approach to professional development among teachers. Professional Development in Education, 46(1), 160-174. doi:https://doi.org/10.1080/19415257.2018.1555183

Hervie, D. M., \& Winful, E. C. (2018). Enhancing teachers' performance through training and development in Ghana education service (A case study of Ebenezer senior high school). Journal of Human Resource Management, 6(1), 1-8. doi:10.11648/j.jhrm.20180601.11

Hubers, M. D., Endedijk, M. D., \& Veen, K. V. (2020). Effective characteristics of professional development programs for science and technology education. Professional Development 
Isniwati et al., 2019 / Supervision and participation in teachers working group toward the teachers professional competence

\begin{tabular}{|c|c|c|c|c|}
\hline Education, & $46(2)$ & $1-20$ & Educational & Evaluation, \\
\hline
\end{tabular}

doi:10.1080/19415257.2020.1752289

Idris, M. (2016). The impact of supervision, motivation and work ethic on teachers' professional competence: a case study of private Islamic high school teachers. International Journal of Human Resource Studies, 6(1), 147-158. doi:http://dx.doi.org/10.5296/ijhrs.v6i1.9073

Iroegbu, E. E., \& Etudor-Eyo, E. (2016). Principals' instructional supervision and teachers' effectiveness. British Journal of Education, 4(7), 99-109.

Jhang, F. H. (2019). Teachers' attitudes towards lesson study, perceived competence, and involvement in lesson study: Evidence from junior high school teachers. Professional Development in Education, 46(1), 82-96. doi:https://doi.org/10.1080/19415257.2019.1585383

Jong, L. d., Meirink, J., \& Admiraal, W. (2019). School-based teacher collaboration: Different learning opportunities. Teaching and Teacher Education, 86, 1-12. doi:https://doi.org/10.1016/j.tate.2019.102925

Kennedy, A. (2005). Models of continuing professional development: A framework for analysis. Journal of In-service Education, 31(2), 235-250. doi:10.1080/13674580500200277

Kennedy, M. M. (2016). How does professional development improve teaching? Review of Educational Research, 86(4), 945-980. doi:https://doi.org/10.3102/0034654315626800

Kennedy, M. M. (2019). How We Learn About Teacher Learning. Review of Research in Education, 43(1), 138-162. doi: https://doi.org/10.3102/0091732X19838970

Khan, S., \& Abdullah, N. N. (2019). The impact of staff training and development on teachers' productivity. Economics, Management and Sustainability, 4(1), 37-45. doi:10.14254/jems.2019.4-1.4

Kiany, G. R., \& Shayestefar, P. (2011). High school students' perceptions of EFL teacher control orientations and their English academic achievement. British Journal of Educational $\begin{array}{lll}\text { Psychology, } & \text { 81(3), } & \text { 491-508. }\end{array}$ doi:https://doi.org/10.1348/000709910X522177

Koellner, K., \& Jacobs, J. (2015). Distinguishing Models of Professional Development: The Case of an Adaptive Model's Impact on Teachers' Knowledge, Instruction, and Student Achievement. Journal of Teacher Education, 66(1), 51-67. doi:https://doi.org/10.1177/0022487114549599

Kraft, M. A., \& Gilmour, A. (2016). Can principals promote teacher development as evaluators? a case study of principals' views and experiences. Educational Administration Quarterly, 52(5), 711-753. doi:https://doi.org/10.1177/0013161X16653445

Luyten, H., \& Bazo, M. (2019). Transformational leadership, professional learning communities, teacher learning and learner centred teaching practices: Evidence on their interrelations in Mozambican primary education. Studies in doi:10.1016/j.stueduc.2018.11.002

Maaranen, K., Kynäslahti, H., Byman, R., Sintonen, S., \& Jyrhämä, R. (2020). Do you mean besides researching and studying?' Finnish teacher educators' views on their professional development. Professional Development in Education, 46(1), 35-48. doi:https://doi.org/10.1080/19415257.2018.1555184

Mahler, D., Großschedl, J., \& Harms, U. (2018). Does motivation matter? The relationship between teachers' self-efficacy and enthusiasm and students' performance. Plos One, 13(11), e0207252. doi:https://doi.org/10.1371/journal.pone.0207252

McChesney, K., \& Aldridge, J. M. (2019). A review of practitioner-led evaluation of teacher professional development. Professional Development in Education, 45(2), 307-324. doi:https://doi.org/10.1080/19415257.2018.1452782

Muelasa, A., \& Navarroa, E. (2015). Learning strategies and academic achievement. Procedia - Social and Behavioral Sciences, 165, 217- 221. doi:10.1016/j.sbspro.2014.12.625

National Education Department. (2009). Pedoman pengelolaan gugus sekolah dasar (Elementary school cluster management guidelines). Jakarta: Directorate General of Primary and Secondary Education Management.

National Ministry of Education. (2009). Standar pendidikan anak usia dini (Early childhood education standards). Jakarta: National Ministry of Education.

Osman, D. J., \& Warner, J. R. (2020). Measuring teacher motivation: The missing link between professional development and practice. Teaching and Teacher Education, 92(2020), 1-12. doi:https://doi.org/10.1016/j.tate.2020.103064

Ozdemir, T. Y., \& Yirci, R. (2015). A situational analysis of educational supervision. Educational Process: International Journal, 4(12), 56-70. doi:http://dx.doi.org/10.12973/edupij.2015.412.5

Sarfo, F. K., \& Cudjoe, B. (2016). Supervisors' knowledge and use of clinical supervision to promote teacher performance. International Journal of Education and Research, 4(1), 87-100.

Schaap, H., \& Bruijn, E. d. (2018). Elements affecting the development of professional learning communities in schools. Learning Environments Research, 21, 109-134. doi:https://doi.org/10.1007/s10984-017-9244-y

Schaap, H., Louws, M., Meirink, J., Oolbekkink-Marchand, H., Want, A. V., Zuiker, I., .. Meijer, P. (2019). Tensions experienced by teachers when participating in a professional learning community. Professional Development in Education, 45(5), 814-831.

doi:https://doi.org/10.1080/19415257.2018.1547781

Timperley, H., \& Alton-Lee, A. (2008). Reframing teacher professional learning: An alternative policy approach to strengthening valued outcomes for diverse learners. Review of Research in Education, 32(1), 328-369. doi:https://doi.org/10.3102/0091732X07308968 
Isniwati et al., 2019 / Supervision and participation in teachers working group toward the teachers professional competence

Tulbure, C. (2012). Learning styles, teaching strategies and academic achievement in higher education: A cross-sectional investigation. Procedia - Social and Behavioral Sciences, 33, 398 - 402. doi:https://doi.org/10.1016/j.sbspro.2012.01.151

Yousaf, S. U., Usman, B., \& Islam, T. (2018). Effects of supervision practices of principals on work performance and growth of primary school teachers. Bulletin of Education and Research, 40(1), 285-298.

Zhang, S., \& Liu, Q. (2019). Investigating the relationships among teachers' motivational beliefs, motivational regulation, and their learning engagement in online professional learning communities. Computers \& Education, 134, 145-155. doi:https://doi.org/10.1016/j.compedu.2019.02.013. 